\title{
Stent grafting in Marfan syndrome? We are not convinced
}

\author{
Stephen D. Waterford, MD, and Marc R. Moon, MD
}

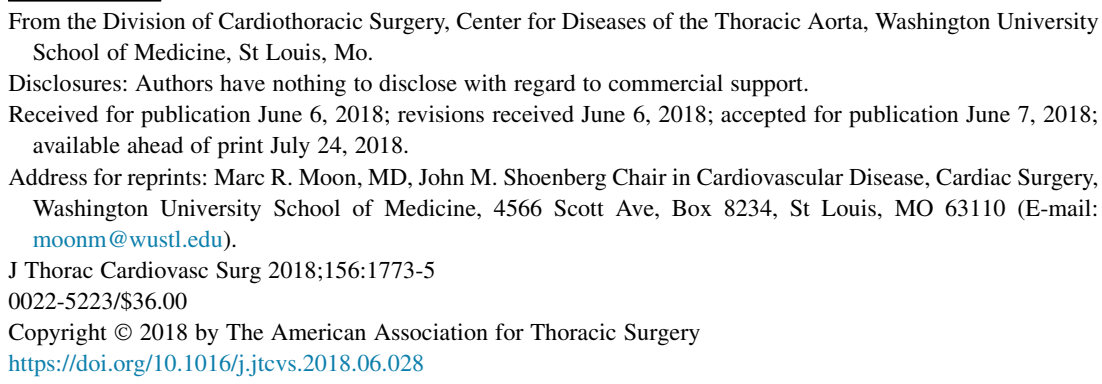

From the Division of Cardiothoracic Surgery, Center for Diseases of the Thoracic Aorta, Washington University School of Medicine, St Louis, Mo.

Disclosures: Authors have nothing to disclose with regard to commercial support.

Received for publication June 6, 2018; revisions received June 6, 2018; accepted for publication June 7, 2018; available ahead of print July 24, 2018.

Address for reprints: Marc R. Moon, MD, John M. Shoenberg Chair in Cardiovascular Disease, Cardiac Surgery, Washington University School of Medicine, 4566 Scott Ave, Box 8234, St Louis, MO 63110 (E-mail: moonm@wustl.edu).

J Thorac Cardiovasc Surg 2018;156:1773-5

$0022-5223 / \$ 36.00$

Copyright (C) 2018 by The American Association for Thoracic Surgery

https://doi.org/10.1016/j.jtcvs.2018.06.028

In this issue of the Journal, Faure and colleagues ${ }^{1}$ present a well-executed, novel approach to stent grafting in patients with Marfan syndrome. To summarize, they describe a strategy for treatment of type B dissection in which a stent graft is used to cover the entry tear of a type B dissection, and bare-metal, uncovered stents are used to expand the intimal flap against the adventitially bound false lumen. They term this technique STABILISE. As a bit of background, this is an evolution of a technique in which a covered stent was used to cover the entry tear and bare-metal, uncovered stents were used to line the true lumen of the distal aorta, but without expanding the bare-metal stent to appose the intimal flap with the adventitially bound false lumen. This was termed the STABLE strategy. ${ }^{2}$ The putative advantage of the STABILISE strategy is that the false lumen is obliterated at the index procedure by balloon expansion of the bare-metal stent. The requirement for future reverse remodeling in the stented segment is thus eliminated, because the false lumen is obliterated at the index procedure within the stented segment, although the false lumen remains patent distally beyond the stents, as was demonstrated experimentally with this approach in $1991 .{ }^{3}$

Faure and colleagues ${ }^{1}$ present data showing fewer periprocedural complications than have been reported by other experienced centers with stent grafting in connective tissue disease. One can only conclude either that device technology has improved-they used the covered stent-graft C-TAG device proximally (Conformable Gore TAG stent graft; W.L. Gore \& Associates, Flagstaff, Ariz) and the uncovered nitinol Zenith Dissection Endovascular Stent device distally (Cook Medical, Bloomington, Ind)—or that their procedural technique is particularly delicate in these dissected, abnormal aortas. Either way, however, it is an overstatement to call the reported results midterm outcomes, because the median follow-up is 15 months, which is short given the long-term outlook in patients with Marfan syndrome.

One also must emphasize the principles and literature regarding stent grafting in patients with Marfan syndrome and other connective tissue disorders. In an expert

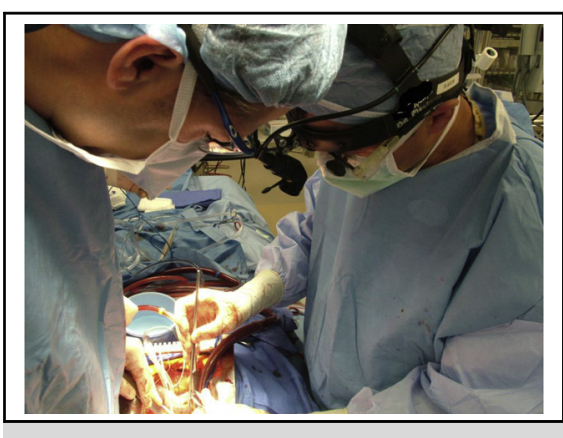

Open surgery remains the criterion standard for patients with Marfan syndrome.

Central Message

Stent grafting in Marfan syndrome remains questionable in light of numerous studies demonstrating high morbidity and mortality. Open operation carries low risk and remains the treatment of choice.

See Article page 1787.

consensus document from the Society of Thoracic Surgeons, stent grafting is not recommended in patients with Marfan syndrome and connective tissue disorders unless the risk of open surgical repair is prohibitive. Further, because these patients are young and the durability of stent grafts is unknown, and because the radial force of stent grafts on abnormal aortas is considered risky, stent graft placement is deemed not prudent and to be avoided. ${ }^{4}$ The 2010 American Heart Association guidelines similarly recommend open operation for treatment of aneurysms resulting from descending thoracic aortic dissection, particularly in the setting of connective tissue disease, in a document coauthored with the American Association for Thoracic Surgery and the Society for Thoracic Surgery. ${ }^{5}$ Similarly, the 2014 European Society of Cardiology guidelines recommend consideration of endografting in patients with Marfan syndrome only in emergencies or as a bridge to definitive surgical therapy. ${ }^{6}$

The complications associated with stenting or stent grafting in patients with connective tissue disorders have been widely described. First, there is a remarkably high rate of endoleak necessitating operative intervention, owing to continued dilation of the abnormal aorta, which is left in situ and used as a landing zone. In a systematic review from the University of Bologna, the overall postprocedural endoleak rate was $29 \%$ when stent grafts were landed in native aorta in patients with Marfan syndrome. ${ }^{7}$ The vast 
majority of endoleaks were type I, occurring at the junction of the stent graft with the aorta. Conversion to open surgery was necessary in $18 \%$ of patients. Mortality was $12.8 \%$ at 2.5-year follow-up, and most deaths were aortic related. Similarly, in a series of 16 patients with Marfan syndrome who underwent 19 stent-grafting procedures for descending thoracic and abdominal aortic pathology, $44 \%$ had primary treatment failure, with most of these failures necessitating conversion to an open operation, and there was a $25 \%$ mortality at 9.3 months. ${ }^{8}$ Overall, at 6.8 -month follow-up, only $38 \%$ had a successful endovascular procedure and required no subsequent interventions, and 1 of these patients died of multiorgan failure. Treatment failures in this series included cases of type I endoleak, as well as that of a patient who had a retrograde type A dissection, a life-threatening complication. Retrograde type A dissection is a known complication of stent grafting in type B dissection, and its risk is greatly elevated in patients with Marfan syndrome. ${ }^{9}$ In fact, despite the tendency to exclude patients with Marfan syndrome from stent grafting, between $13.5 \%$ and $27 \%$ of retrograde type A dissections reported in the literature occur in patients with Marfan syndrome.

Consistent with the data on endoleaks in patients with Marfan syndrome, Faure and colleagues ${ }^{1}$ report that 1 in 7 patients at 15 months required an arch replacement to manage a type Ia endoleak. This endoleak resulted from the continued enlargement—which one would expect—of the native Marfan aorta. Arch replacement in this case would likely have been avoided by open repair of the type $\mathrm{B}$ dissection as the index operation, ideally after a 4- to 6-week period to stabilize the dissection before elective replacement. The finding of Faure and colleagues ${ }^{1}$ represents a failure rate of $15 \%$ at 15 months, consistent with the expected failure rate derived from reports of stent grafting in the literature.

Long-term risk of rupture is not reduced, and may be increased, by the STABILISE treatment. In this technique, when balloons are used to expand the uncovered metal stent against the intimal flap, this flap, because of fenestrations, will not entirely reappose with the adventitia. Therefore, relamination-a word in the STABILISE acronym-is misleading because the 3 layers of the aorta are not rejoined along its entire length. There are areas of bare adventitia not lined with intima that are up against an uncovered metal stent that has been expanded against this adventitia, which is in contact with pressurized blood in the aorta. Such expansion of an uncovered stent against weak adventitia in a connective tissue disorder may pose a high risk for rupture in the long run.

When is stent grafting appropriate for patients with Marfan syndrome and other connective tissue disorders? We suggest 3 circumstances. ${ }^{10}$ First, if the stent graft can be placed between 2 previously placed surgical grafts, this is acceptable because the landing zones for the stent graft will not dilate with time. Second, intercostal patch aneurysms after open thoracoabdominal aneurysm repair are difficult to expose surgically and represent an important area for stent grafting. In these cases, the stent graft will also lie within a surgical graft, consistent with the previously stated principle. More liberal use of multibranched grafts to reconstruct the visceral segment should decrease this challenging long-term sequela of side-to-side visceral patch anastomoses. Third, emergency cases of rupture can arguably be addressed with stent grafting if the perceived surgical risk is too high for open repair or if a later open surgical revision is planned. Otherwise, the literature confirms that elective repair of type B dissection in patients with Marfan syndrome should be done by open operation. Although the new technology and complex acronyms make STABILISE appear attractive, one must recall that patients with connective tissue disorders are young, and they tend to be excellent operative candidates who seek restoration of a nearly normal life expectancy and reinterventionfree long-term survival. In the largest series of open surgical repair of descending thoracoabdominal aortic aneurysms in the setting of dissection in patients with Marfan syndrome, Coselli and colleagues ${ }^{11}$ describe an operative mortality of $4 \%$, lower than many endovascular series, and a freedom from late repair failure of $86 \%$ at 8 years, well above that of any endovascular series. We continue to advocate for open operations for these patients.

In summary, stent grafting in patients with Marfan syndrome remains questionable in light of numerous studies demonstrating high rates of subsequent open operation for aneurysm expansion and type Ia endoleak, stent graftinduced dissection including retrograde type A dissection, and risk of rupture in segments treated with uncovered metal stents. Open operation has low rates of morbidity and mortality in the young population with Marfan syndrome, and it remains the treatment of choice for type B dissection and thoracoabdominal aneurysm in this population.

\section{References}

1. Faure EM, El Batti S, Rjeili MA, Ben Abdallah I, Julia P, Alsac JM. Stent-assisted, balloon-induced intimal disruption and relamination of aortic dissection in patients with Marfan syndrome: midterm outcomes and aortic remodeling. $J$ Thorac Cardiovasc Surg. 2018;156:1787-93.

2. Hofferberth SC, Foley PT, Newcomb AE, Yap KK, Yii MY, Nixon IK, et al. Combined proximal endografting with distal bare-metal stenting for management of aortic dissection. Ann Thorac Surg. 2012;93:95-102.

3. Moon MR, Dake MD, Pelc LR, Liddell R, Castro LJ, Mitchell RS, et al. Intravascular stenting of acute experimental type B dissections. J Surg Res. 1993;54: 381-8.

4. Svensson LG, Kouchoukos NT, Miller DC, Bavaria JE, Coselli JS, Curi MA, et al. Expert consensus document on the treatment of descending thoracic aortic disease using endovascular stent-grafts. Ann Thorac Surg. 2008;85(1 Suppl): S1-41.

5. Hiratzka LF, Bakris GL, Beckman JA, Bersin RM, Carr VF, Casey DE Jr, et al; American College of Cardiology Foundation/American Heart Association Task Force on Practice Guidelines; American Association for Thoracic Surgery; American College of Radiology; American Stroke Association; Society of 
Cardiovascular Anesthesiologists; Society for Cardiovascular Angiography and Interventions; Society of Interventional Radiology; Society of Thoracic Surgeons; Society for Vascular Medicine. 2010 ACCF/AHA/AATS/ACR/ASA/ SCA/SCAI/SIR/STS/SVM guidelines for the diagnosis and management of patients with thoracic aortic disease. A Report of the American College of Cardiology Foundation/American Heart Association task force on practice guidelines, American Association for Thoracic Surgery, American College of Radiology, American Stroke Association, Society of Cardiovascular Anesthesiologists, Society for Cardiovascular Angiography and Interventions, Society of Interventional Radiology, Society of Thoracic Surgeons, and Society for Vascular Medicine. J Am Coll Cardiol. 2010;55:E27-129. Erratum in: J Am Coll Cardiol. 2013;62:1039-40

6. Erbel R, Aboyans V, Boileau C, Bossone E, Bartolomeo RD, Eggebrecht H, et al; ESC Committee for Practice Guidelines. 2014 ESC guidelines on the diagnosis and treatment of aortic diseases: document covering acute and chronic aortic diseases of the thoracic and abdominal aorta in the adult. The task force for the diag- nosis and treatment of aortic diseases of the European Society of Cardiology (ESC). Eur Heart J. 2014;35:2873-926. Erratum in: Eur Heart J. 2015:36:2779.

7. Pacini D, Parolari A, Berretta P, Di Bartolomeo R, Alamanni F, Bavaria J. Endovascular treatment for type B dissection in Marfan syndrome: is it worthwhile? Ann Thorac Surg. 2013;95:737-49.

8. Waterman AL, Feezor RJ, Lee WA, Hess PJ, Beaver TM, Martin TD, et al. Endovascular treatment of acute and chronic aortic pathology in patients with Marfan syndrome. J Vasc Surg. 2012;55:1234-40; discussion 1240-1.

9. Dong ZH, Fu WG, Wang YQ, Guo DQ, Xu X, Ji Y, et al. Retrograde type A dissection after endovascular stent graft placement for treatment of type B dissection. Circulation. 2009;119:735-41.

10. Kouchoukos NT. Endovascular surgery in Marfan syndrome: CON. Ann Cardiothorac Surg. 2017;6:677-81.

11. Coselli JS, Green SY, Price MD, Hash JA, Ouyang Y, Volguina IV, et al. Results of open surgical repair in patients with Marfan syndrome and distal aortic dissection. Ann Thorac Surg. 2016;101:2193-201.

Access to The Journal of Thoracic and Cardiovascular Surgery Online is reserved for print subscribers!

Full-text access to The Journal of Thoracic and Cardiovascular Surgery Online is available for all print subscribers. To activate your individual online subscription, please visit The Journal of Thoracic and Cardiovascular Surgery Online, point your browser to http://www.mosby.com/jtcvs, follow the prompts to activate your online access, and follow the instructions. To activate your account, you will need your subscriber account number, which you can find on your mailing label (note: the number of digits in your subscriber account number varies from 6 to 10 ). See the example below in which the subscriber account number has been circled:

\section{Sample mailing label}

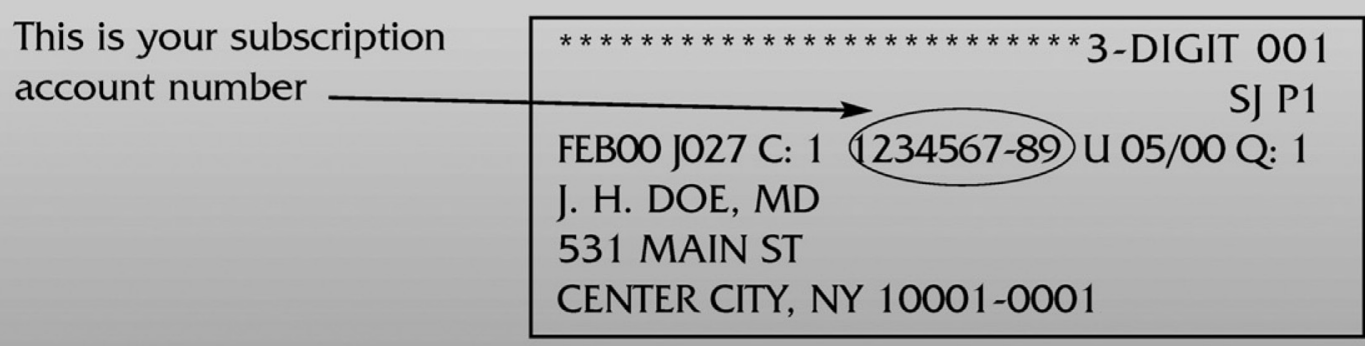

Personal subscriptions to The Joumal of Thoracic and Cardiovascular Surgery Online are for individual use only and may not be transferred. Use of The Journal of Thoracic and Cardiovascular Surgery Online is subject to agreement to the terms and conditions as indicated online. 